\title{
Partial Sequence and Survey Analysis Identify a Multipartite, Negative-Sense RNA Virus Associated with Fig Mosaic
}

\author{
Jeewan Jyot Walia, Nida M. Salem, and Bryce W. Falk, Department of Plant Pathology, University of California, \\ Davis
}

\begin{abstract}
Walia, J. J., Salem, N. M., and Falk, B. W. 2009. Partial sequence and survey analysis identify a multipartite, negative-sense RNA virus associated with fig mosaic. Plant Dis. 93:4-10.

RNA and nucleotide sequence-based analyses were used to identify viruses in fig mosaic (FM)affected fig (Ficus carica) trees. Nucleotide sequence analyses of 267 cloned cDNAs identified sequences corresponding to four viruses representing four distinct taxa from fig trees in California. Virus sequences corresponding to members of the family Closteroviridae were most common (55 sequences). We also found two sequences for an Umbravirus, one sequence corresponding to a Luteovirus-associated RNA, and two sequences that showed homology to European mountain ash ringspot-associated virus (EMARAV). Reverse transcriptionpolymerase chain reaction (RT-PCR) and northern hybridization analyses were used to confirm the presence of specific virus RNAs in fig trees. A survey of 184 fig trees from a germplasm collection, a commercial orchard, backyards, and feral fig trees showed that one virus was most common (detected in $96 \%$ of tested samples), while none of the other virus sequences were detected in more than $36 \%$ of the fig trees. Based on its association with FM-affected trees, nucleotide sequence-based phylogenetic association, and previous reported properties, we suggest the name of this virus as Fig mosaic-associated virus (FMaV).
\end{abstract}

Common edible fig (Ficus carica) is one of the earliest cultivated plants, and the disease fig mosaic (FM) is associated with figs wherever they are grown $(17,18)$. FM was first described by Condit and Horne in 1933 (5), and it has long been suspected to be of viral origin. Since its initial report, FM has been reported from various countries including: Greece, Italy, Spain, Turkey, Syria, Tunisia, Algeria, Jordan, New Zealand, China, Britain, Puerto Rico, Australia, and the United States (2). Affected plants show mosaic symptoms on both leaves and fruits; symptoms vary in their severity on different fig cultivars, growing regions, and even seasonally (12). The leaves can become severely deformed, chlorotic, and show various patterns of vein banding, vein clearing, and discoloration (Fig. 1). FM also often leads to defoliation and premature fruit drop. There is a direct relationship between severity of symptoms and size, quantity, and quality of fruit yield. Due to increasing market demand for fresh and dried figs worldwide, there is increased

Corresponding author: Bryce W. Falk

E-mail: bwfalk@ucdavis.edu

Accepted for publication 30 September 2008.

doi:10.1094/PDIS-93-1-0004

(C) 2009 The American Phytopathological Society urgency among growers and researchers to address FM.

The etiology of FM is still uncertain, although several attempts have been made to identify the causal agent $(8,9,11)$. The Eighth Report of the International Committee on Taxonomy of Viruses lists two taxonomically distinct viruses from figs, Fig virus $S$ (FVS) genus Carlavirus, and Fig leaf chlorosis virus (FLCV) family Potyviridae (11). Recent studies from Italy also identified two different closteroviruses associated with FM-affected figs $(8,9)$, but did not suggest causality. All studies so far suggest that fig trees may have a complex of viruses associated with them, but the virus(es) that causes FM remains unknown.

Ultrastructural studies have shown FMaffected plants to have a characteristic cytopathology. The cells of the symptomatic plants contain quasi-spherical, double-membrane-bound particles (DMPs) of 100 to $200 \mathrm{~nm}$ in diameter present in the cytoplasm $(1,3)$. This interesting cytopathological feature has been observed for several other poorly characterized virus diseases, including the High Plains disease of corn and wheat, rose rosette, wheat spot mosaic, Sterility mosaic disease of pigeon pea, and yellow ring spot of redbud $(1,16,18)$. The nature of the DMPs is not currently known; they have proven to be difficult to isolate from affected plants (16). Eriophyid mites are reported to be the vectors of the viruses associated with these diseases (16), and Flock and Wallace (13) and Proeseler (24) have reported that the causal agent of FM is spread by the fig eriophyid mite, Aceria ficus. The transmission by mites and the characteristic cytopathology suggest that the virus causing FM may be related to these other as yet uncharacterized plant viruses.

Identifying viruses in FM-affected fig trees is the first step toward elucidating the etiology of FM. In the current study, we took a double-stranded RNA (dsRNA) based nucleotide sequence approach to identify viruses from FM-affected figs and assessed the incidence of different viruses in a survey of FM-affected trees. Our results showed that a virus which has sequence homology to European mountain ash ringspot-associated virus (EMARAV) was detected in almost all the tested symptomatic fig trees. Based on our combined analyses, we suggest the name for this putative virus as Fig mosaic associated virus $(\mathrm{FMaV})$.

\section{MATERIALS AND METHODS}

Plant materials. Fig trees showing typical FM symptoms at the USDA, National Clonal Germplasm Repository, University of California, Davis were used for the isolation of double-stranded RNA (dsRNA). The repository currently holds 150 fig accessions (14) collected from many parts of the world. Plants of all accessions showed varying degree of FM symptoms on visual inspection. We also collected 184 samples to conduct a survey for the presence of different viruses associated with FM-affected fig trees. Leaf samples were collected from 50 different trees at National Germplasm Repository (USDA, UC Davis). Seventy-five samples, 25 each of three cultivars, were collected from commercial fig orchards in Fresno County. Thirty-one samples were obtained from the California Department of Food and Agriculture, Riverside. Twenty-six backyard fig trees from Davis and Riverside, and two feral fig samples collected from Yuba County were also tested. FMfree fig seedlings (provided to us by Mallikarjuna Aradhya, USDA) were grown in a controlled environmental chamber, and in the greenhouse. Fig trees identified by us as having specific combinations of vi- 
ruses were propagated by rooting the cuttings using rooting hormone (Rootone, Gardentech, Bayer), and rooted stems were maintained in the greenhouse.

dsRNA extraction and cDNA synthesis. dsRNAs were isolated from $30 \mathrm{~g}$ of bark scrapings and leaves from symptomatic fig trees. The tissues were pulverized in liquid nitrogen and then purified using 2 cycles of CF-11 (Whatman, Springfield Mill, England) column chromatography followed by ethanol precipitation (26). The dsRNA pellet was dissolved in TE buffer ( $1 \mu \mathrm{l} / \mathrm{g}$ of starting tissue) and analyzed by polyacrylamide gel electrophoresis and dsRNAs detected by silver nitrate staining (25).

cDNAs were synthesized using random oligonucleotide primers, and dsRNAs as templates (25). The cDNA library was synthesized from a pool of dsRNAs extracted from two different trees. The dsRNAs were denatured with $20 \mathrm{mM}$ methyl mercuric hydroxide and heating at $94^{\circ} \mathrm{C}$ for $5 \mathrm{~min}$. The SuperScript Choice System for cDNA synthesis (Invitrogen Corp., Carlsbad, CA) was used to construct a cDNA library following the manufacturer's instructions. The doublestranded cDNAs were ligated into pGEM-
T Easy (Promega, Madison, WI) vector and transformed into Escherichia coli $10 \mathrm{G}$ supreme electrocompetent cells (Lucigen Corp., Middleton, WI). Recombinant colonies were selected and grown in LuriaBertani Broth containing $100 \mu \mathrm{g} / \mathrm{ml}$ ampicillin (Sigma Chemical Co., St Louis, MO). Plasmids were purified using the FastPlasmid Mini (Eppendorf, Westbury, $\mathrm{NY}$ ), digested with EcoRI, and analyzed by agarose gel electrophoresis to determine the insert size.

Nucleotide sequence analysis. After initial screens to assess cDNA library quality, 267 colonies were selected for nucleotide sequence analysis. Sequencing was performed using an AB1373 Automated Sequencer at the CAES Genomics Facility (CGF), University of California, Davis. The resulting sequences were analyzed using sequence analysis and data management software from Invitrogen (Vector NTI Advance). Sequences were compared with nucleotide and protein databases (GenBank, NCBI) using BLASTn and BLASTx programs available from NCBI in attempts to identify plant virus sequences.

Northern blot hybridization and reverse transcription-polymerase chain reaction (RT-PCR) analysis. Total RNAs extracted from the symptomatic fig trees (Qiagen RNeasy Plant mini kit) and dsRNAs were denatured with dimethylsulfoxide and glyoxal, and analyzed by $1 \%$ agarose gel electrophoresis, followed by transfer to Hybond $\mathrm{N}^{+}$membranes (Amersham Biosciences, Piscataway, NJ) (27). Five clones were used to generate RNA transcript probes for use in the northern hybridization analyses. These corresponded to sequences showing similarity to the four different viruses identified by sequence analyses (Table 1$)$. The $\left[\alpha-{ }^{32} \mathrm{P}\right]-$ UTP labeled RNA probes were generated using the Sp6/T7 MAXIscript in vitro transcription kit (Ambion, Austin, TX) so as to generate probes predicted to be of negative polarity. The prehybridization and hybridization were carried according to instructions provided by Perfect Hyb. Plus buffer from Sigma.

RT-PCR was used to screen fig trees for the presence of specific viruses. Sequences showing identity $(\geq 34 \%)$ to different plant virus sequences were used to design oligonucleotide primers for RT-PCR. The one-step RT-PCR (22) was performed at $52^{\circ} \mathrm{C}$ for $30 \mathrm{~min}$ (reverse transcription), $94^{\circ} \mathrm{C}$ for $30 \mathrm{~s}, 54^{\circ} \mathrm{C}$ for $45 \mathrm{~s}, 72^{\circ} \mathrm{C}$ for 1

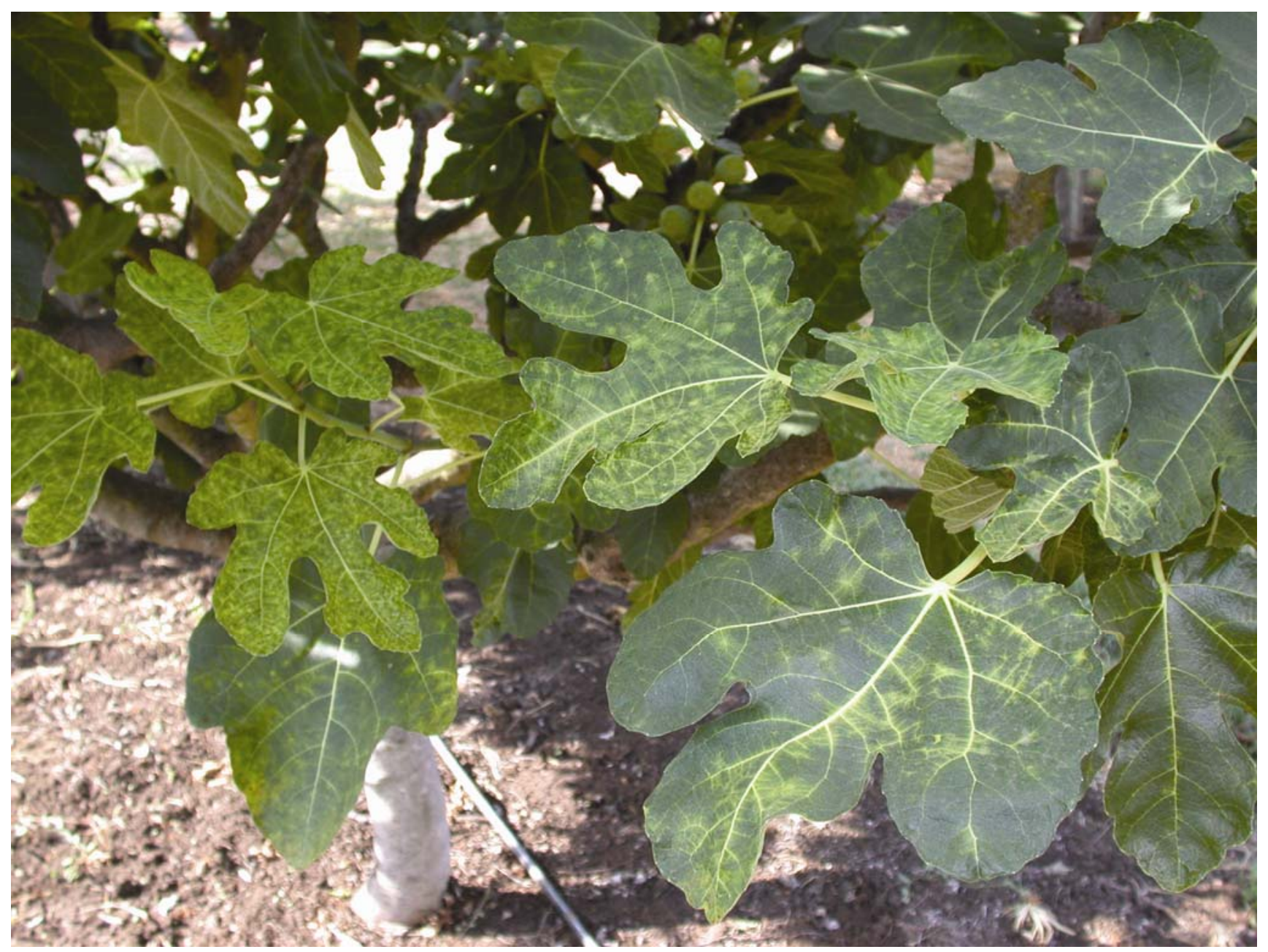

Fig. 1. Interveinal chlorosis and mosaic on the leaves of fig mosaic-affected fig trees. 
min for 35 cycles, and final extension for 7 min at $72^{\circ} \mathrm{C}$. Products were analyzed by agarose gel electrophoresis and ethidium bromide staining.

\section{RESULTS}

dsRNA analysis. Fig trees and many other woody plants have polyphenolics and polysaccharides, making it difficult to obtain high quality and quantity of dsRNAs; therefore modifications to the standard dsRNA isolation protocols $(6,31)$ were made as described (25). Polyacrylamide gel electrophoresis and silver nitrate staining allowed resolution of multiple species of dsRNAs, but a relatively abundant, high molecular weight dsRNA was most prominent (Fig. 2). This dsRNA migrated more slowly than did the largest dsRNA marker used by us, $5.8 \mathrm{~kb}$, and thus we were unable to accurately determine its size from these experiments. The faster migrating dsRNAs showed some differences in mobility and intensity among different samples. This could be because the different samples were purified from different fig trees of distinct genotypes, or they might represent different RNA viruses present in the different plants. Thus, we were unable to identify specific viruses just by dsRNA analysis, but the presence of abundant dsRNAs suggested that RNA viruses were present in these fig trees.

cDNA library synthesis and sequence analysis. In order to identify RNA virus sequences from FM-affected fig plants, we constructed a cDNA library using the dsRNAs as templates. We screened plasmids from this library by restriction enzyme digestion and agarose gel electrophoresis. All of the plasmids contained cDNA inserts ranging in size from $\sim 150$ to 800 nucleotides. We then used 244 recombinant colonies for nucleotide sequence analysis in order to compare these se- quences with those in databases. Twentythree more colonies were selected from an additional cDNA library synthesized from dsRNA extracted from a different fig tree infected with $\mathrm{FMaV}$, and sequenced as well. In silico analysis confirmed that within these libraries most of the resulting sequences were noninformative. Many sequences showed homology to plant sequences, bacterial sequences, and for 67 no sequence homology was found. However, BLASTx showed that translated sequences for 60 of the cDNAs had high amino acid identities to plant viruses representing four different virus taxa, including the genera
Closterovirus, Umbravirus, the unassigned luteovirus-associated RNAs, and the recently sequenced European mountain ash ringspot-associated virus (EMARAV, no genus; Table 1).

Fifty-five of the 60 sequences showed significant amino acid identities with proteins encoded by viruses in the family Closteroviridae. BLASTx analysis suggested that some of the cDNAs analyzed here were similar to the recently described Fig leaf mottle-associated virus1 (FLMaV1) (e.g., accession numbers CAJ34535 and CAK50812), suggesting that FLMaV too is present in at least some of the FM-

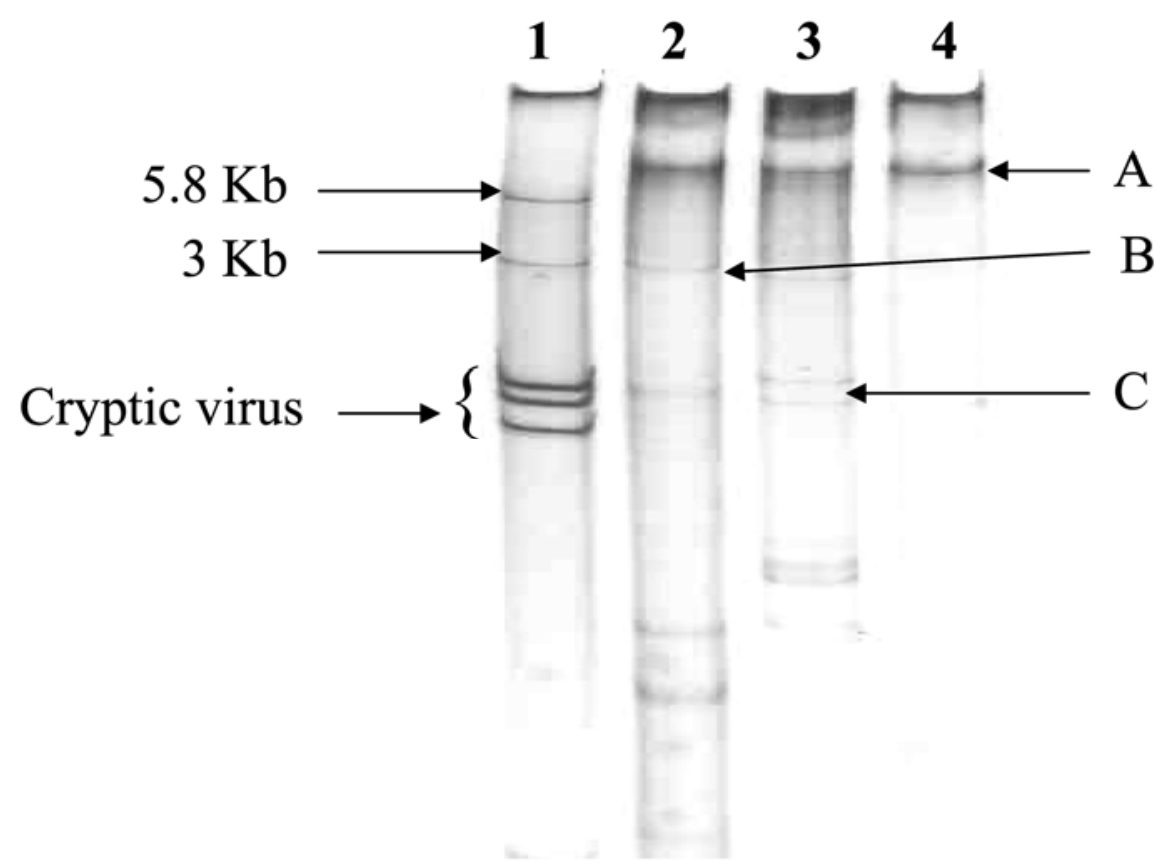

Fig. 2. Polyacrylamide gel electrophoresis (6\% in Tris-acetate-EDTA) of double-stranded (ds)RNAs from fig mosaic (FM)-affected trees. Lane 1, dsRNA (control) from a rose plant affected with Rose spring dwarf associated virus and Rosa multiflora cryptic virus (25,26). Lanes 2 to 4, dsRNAs isolated from different FM-symptomatic figs. Note different patterns of dsRNA from different plants as indicated by arrows $\mathrm{A}, \mathrm{B}$, and $\mathrm{C}$.

Table 1. Fig virus cDNA clones and sequence information

\begin{tabular}{|c|c|c|c|c|c|}
\hline $\begin{array}{l}\text { Clone name }^{\mathrm{a}} \\
\text { (accession no.) }\end{array}$ & $\begin{array}{l}\text { Closest homologb } \\
\text { (accession no.) and } \\
\text { encoding sequence }\end{array}$ & $\begin{array}{l}\text { Percent } \\
\text { identity }\end{array}$ & e-Value & Primer sequence $\left(5^{\prime} \text { to } 3^{\prime}\right)^{c}$ & Product size \\
\hline $\begin{array}{l}\text { CRLaRNA } \\
(\text { FJ211075) }\end{array}$ & $\begin{array}{l}\text { Carrot red leaf luteovirus } \\
\text { associated } \mathrm{RNA} \\
\text { (NP_624318) RdRp }\end{array}$ & 40 & 0.002 & $\begin{array}{l}\text { CCAAGAACAATCTGGAGCGC } \\
\text { CGACCTTCGTAGCAGTTGAG }\end{array}$ & 184 bp \\
\hline $\begin{array}{l}\text { EMARAVNP } \\
(\text { FJ211073) }\end{array}$ & $\begin{array}{l}\text { European mountain ash } \\
\text { ringspot-associated virus } \\
\text { (ABH05070) Nucleocapsid }\end{array}$ & 49 & $2 e^{-43}$ & $\begin{array}{l}\text { CACGAGCAAGACAAAGAGAA } \\
\text { CACACTTACACATCTTACATCATCT }\end{array}$ & 298 bp \\
\hline $\begin{array}{l}\text { EMARAVGP } \\
(\text { FJ211074) }\end{array}$ & $\begin{array}{l}\text { European mountain ash } \\
\text { ringspot-associated virus } \\
\text { (AAS73288) Glycoprotein }\end{array}$ & 34 & $1 \mathrm{e}^{-04}$ & $\begin{array}{l}\text { GGGTACATATGCGTCATTCTTG } \\
\text { CGTTTGTCTTGGATCACAGCAA }\end{array}$ & $468 \mathrm{bp}$ \\
\hline $\begin{array}{l}\text { CMMV } \\
\text { (FJ211076) }\end{array}$ & $\begin{array}{l}\text { Carrot mottle mimic virus } \\
\quad\left(\mathrm{NP} \_054006\right) \mathrm{RdRp}\end{array}$ & 44 & 0.003 & $\begin{array}{l}\text { GTACGAATTCGCGTATAGATCGAGG } \\
\text { GCCAATTGCATACCGGGTGT }\end{array}$ & 154 bp \\
\hline $\begin{array}{l}\text { ClosRep } \\
\text { (FJ211077) }\end{array}$ & $\begin{array}{c}\text { Strawberry chlorotic fleck } \\
\text { associated virus } \\
\text { (ABI23183) Replicase }\end{array}$ & 47 & $4 e^{-39}$ & $\begin{array}{l}\text { TGCGAGGGATACTTTGGGACGT } \\
\text { TCGCTCGCCACAGAATGAGAAA }\end{array}$ & 439 bp \\
\hline
\end{tabular}

a Name and accession number for fig virus cDNA clones used here.

${ }^{\mathrm{b}}$ Closest homolog indicates the accession number and virus which showed the highest relationship to the corresponding fig virus cloned cDNA by BLASTx. Values are given in the following two columns. RdRp = RNA-dependent RNA polymerase.

${ }^{c}$ Primers were developed from nucleotide sequences of virus-specific clones and further used in reverse transcription-polymerase chain reaction (RT-PCR). Top primer is forward primer, bottom is reverse primer. Expected product size is shown in the following column. 
affected fig trees growing in California. Of the remaining cloned cDNAs, BLASTx analyses showed 40 and $37 \%$ amino acid identity with the putative RNA-dependent RNA polymerase (RdRp) regions for two members of the luteovirus-associated RNAs (accession numbers NP_624318 [Carrot red leaf luteovirus associated RNA, CtRLVaRNA] and ABV01917 [Tobacco bushy top disease-associated RNA]). Two of the sequences showed high identity with a region of the RdRp of Carrot mottle mimic virus (CMoMV, Umbravirus), accession numbers NP054006 and NP054006.2. Finally, two translated nucleotide sequences showed identity with sequences for EMARAV (21). BLASTx analysis identified the sequences for the nucleocapsid protein (NP) and the glycoprotein (GP) of EMARAV (accession numbers ABH05070 and AAS73288, respectively). The NP also showed $27 \%$ identity to deduced amino acid sequence of the NP of Maize red stripe virus (accession number $\mathrm{ABC} 58222$ ), the causal agent of High Plains disease (28), and $42 \%$ identity to a hypothetical protein of Pigeon pea sterility mosaic virus (accession number CAD28797) (19). The percent amino acid identities and the e-value scores (BLASTx) of the cDNAs showing highest identities to the viral sequences mentioned above are shown in Table 1.

Confirmation and survey of viruses associated with FM. In order to gain more evidence that the sequences identified by us corresponded to fig-infecting viruses, and were not sequence artifacts, we took two separate approaches. First, we performed northern hybridization analyses to determine if RNAs of the predicted sizes for the putative viruses were present in FM-affected figs, and second we performed a widespread survey to assess incidence of the different viruses in fig trees.

Northern hybridization analyses results corroborated our sequencing results. We performed northern hybridization analysis on dsRNAs used for our original testing, and we identified RNAs corresponding to sizes predicted for the respective viruses. For example, viruses of the genus Closterovirus have large genomic RNAs (>15 $\mathrm{kb}$ of ssRNA) and express their genes via numerous subgenomic RNAs (7). Therefore, northern hybridization analysis using an appropriate closterovirus probe should detect genome size and corresponding subgenomic RNAs. When we analyzed dsRNAs and total RNAs from the fig trees used for dsRNA analysis and cDNA library construction by using a probe corresponding to replicase protein (Strawberry chlorotic fleck associated virus; Table 1), we detected a large RNA, much greater in size than our largest ssRNA marker (6.5 $\mathrm{kb}$ ), plus several smaller RNAs (Fig. 3). The latter probably represent subgenomic RNAs or defective RNAs, as these are typical for viruses of the genus Closterovirus (7). Similarly, northern hybridization analysis identified a ssRNA of ca. $2.9 \mathrm{~kb}$ for the sequence showing similarity to the Luteovirus-associated RNA. A ca. $\sim 4 \mathrm{~kb}$ ssRNA was also detected using an RNA probe from the cloned sequence showing similarity to the Carrot mottle mimic virus (Fig. 3; clone CMMV; Table 1). The expected size of the Luteovirus-associated RNAs is $\sim 2.8 \mathrm{~kb}(23)$, and that of the umbraviruses is $\sim 4.2 \mathrm{~kb}(29,30)$, thus strongly supporting our sequence data. We also identified two sequences that showed homology to two different EMARAV genomic RNA segments, encoding the GP and NP. We performed northern hybridization analyses using transcript probes generated from both cloned cDNAs (clones EMARAVNP and EMARAVGP; Table 1), as we predicted that we should detect two different sized RNAs, one for each probe. Both probes hybridized with the test RNAs, both denatured dsRNAs and total RNAs from the FM-affected fig test sample (Fig. 4). These two probes hybridized with RNAs slightly different in size, $\sim 2.1$ and $1.8 \mathrm{~kb}$, respectively, similar in size to the respective genomic RNAs two and three of EMARAV (21). Further evidence that our results represent fig-infecting viruses is that none of the probes used here hybridized with RNAs prepared from healthy fig seedlings.

Because the data presented above strongly suggested that we have identified virus sequences from figs, we next chose to sample figs from several locations in order to assess the incidence of the specific viruses identified so far, and to determine if any or all of these viruses were consistently associated with FM-affected figs We first developed RT-PCR assays for sequences corresponding to the four viruses identified above. RT-PCR analyses

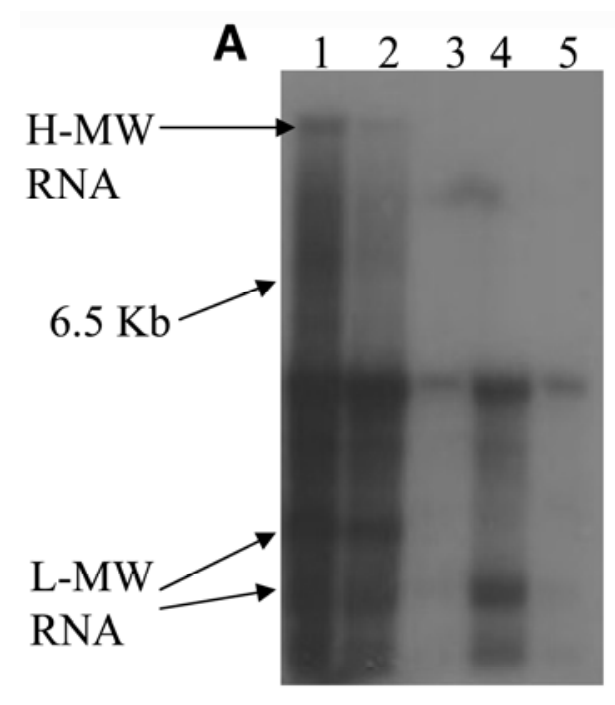

Closterovirus-like
B

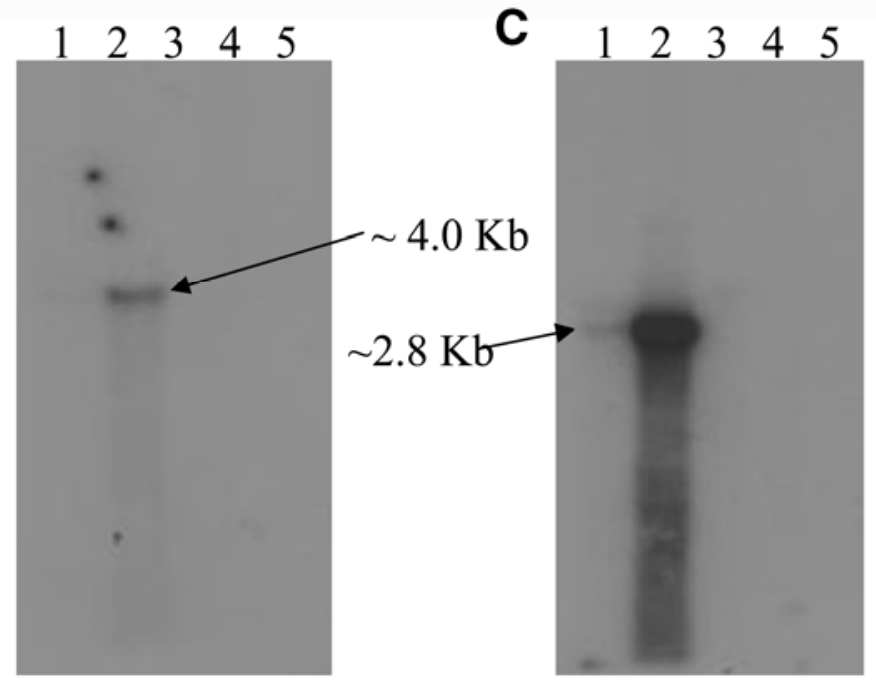

Umbravirus - like

\section{Luteovirus associated RNA}

Fig. 3. Northern blot hybridization analysis of double-stranded (ds)RNAs and total RNAs extracted from fig mosaic (FM)-affected fig trees. RNAs were analyzed by agarose gel electrophoresis under denaturing conditions, transferred to a nitrocellulose membrane, and hybridized with specific probes transcribed from the respective cDNA clones. Blots A, B, and C were probed using ${ }^{32} \mathrm{P}-$ labeled transcripts from clones showing similarity to a cDNA clone from the ClosRep linkage group, CMMV, and CRLaRNA (see Table 1). Approximate sizes of RNAs are indicated in the figure. Lanes 1 and 2 represent dsRNA, and lanes 3, 4, and 5 represent total RNA extracted from FM-affected fig trees. The Closterovirus-like virus blot shows a high molecular weight RNA band and smaller bands typical of Closteroviridae. 
showed that specific products of the expected size were obtained for the respective primer sets (Fig. 5). We then used RT-PCR to test 184 samples from fig trees showing
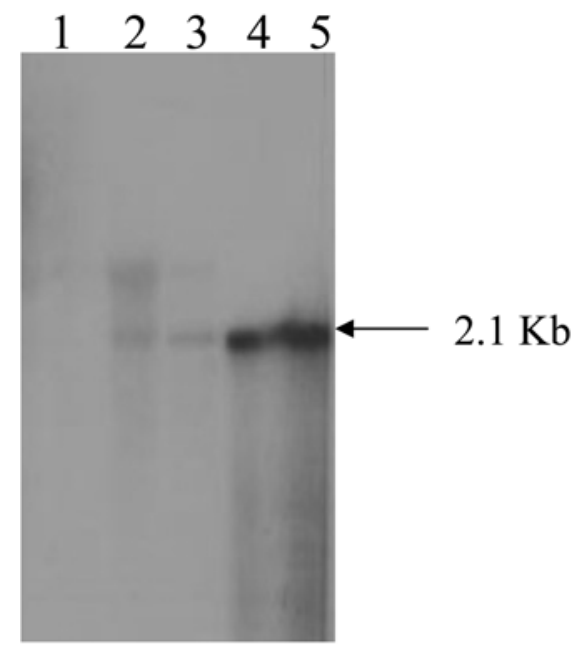

FMaV (GP)
FM symptoms and growing at various locations in California. Interestingly, RT-PCR results for the different samples showed that all of the above-mentioned viruses were not

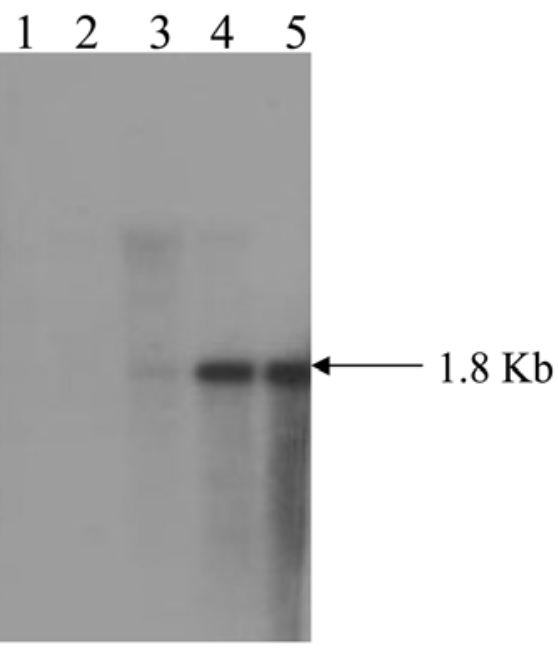

FMaV (NP)

Fig. 4. Northern blot hybridization analysis of double-stranded (ds)RNA and total RNA extracted from fig mosaic (FM)-affected fig trees electrophoresed under denaturing conditions and hybridized with specific probes transcribed from the respective clones EMARAVNP and EMARAVGP (see Table 1). Blots FMaV (NP) and FMaV (GP) were hybridized with EMARAVGP and EMARAVNP probes, respectively. Approximate sizes of RNAs are indicated. Lane 1 represents total RNA extracted from asymptomatic fig seedlings; lanes 2 and 3 represent total RNAs; and lanes 4 and 5 are dsRNAs extracted from FM-affected fig trees.

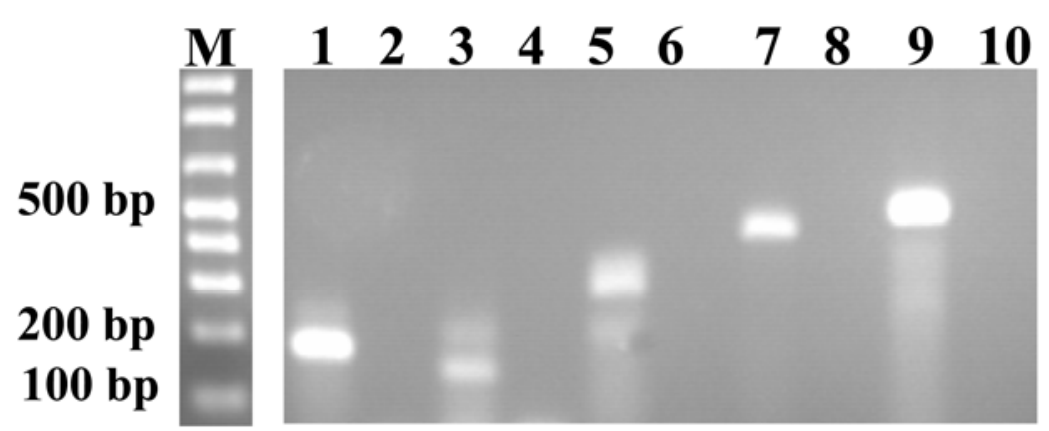

Fig. 5. Reverse transcription-polymerase chain reaction (RT-PCR) for detection of different viruses associated with fig mosaic (FM) by using virus-specific primers. Primers were used in the order CRLaRNA, CMMV, EMARAVNP, ClosRep, and EMARAVGP (see Table 1). Lanes 1, 3, 5, 7, and 9 are RT-PCR products from FM-affected fig trees, and lanes 2, 4, 6, 8, and 10 are water controls. Lane $\mathrm{M}$ is the 1-kb plus DNA ladder. Numbers at left indicate base pairs of DNA standards.

Table 2. Results of reverse transcription-polymerase chain reaction (RT-PCR) analysis and fig virus survey

\begin{tabular}{lcccc}
\hline $\begin{array}{l}\text { Cultivar or type } \\
\text { of sample }\end{array}$ & FMaV $^{\mathbf{a}}$ & $\begin{array}{c}\text { Luteovirus associated } \\
\text { RNA-like }\end{array}$ & $\begin{array}{c}\text { Umbravirus- } \\
\text { like }^{\mathbf{b}}\end{array}$ & $\begin{array}{c}\text { Closterovirus- }^{\text {(ike }} \\
\text { like }^{\mathbf{s}}\end{array}$ \\
\hline Calimyrna & $24 / 25^{\mathrm{e}}$ & $18 / 25$ & $14 / 25$ & $09 / 25$ \\
Black Mission & $25 / 25$ & $13 / 25$ & $10 / 25$ & $00 / 25$ \\
Conadria & $25 / 25$ & $04 / 25$ & $01 / 25$ & $00 / 25$ \\
Feral & $02 / 02$ & $01 / 02$ & $00 / 02$ & $00 / 02$ \\
Backyard & $25 / 26$ & $05 / 26$ & $01 / 26$ & $10 / 26$ \\
USDA germplasm & $48 / 50$ & $09 / 50$ & $12 / 50$ & $40 / 50$ \\
CDFA & $28 / 31$ & $14 / 31$ & $08 / 31$ & $07 / 31$ \\
Total & $177 / 184$ & $64 / 184$ & $46 / 184$ & $66 / 184$ \\
\hline
\end{tabular}

${ }^{a}$ Fig mosaic-associated virus (FMaV) indicates samples that were positive using the EMARAVNP and EMARAVGP primers (see Table 1 for primer designations and sequences).

b Samples positive using CRLaRNA primers.

c Samples positive using the CMMV primers.

d Samples positive using the ClosRep primers.

e Numerator is the number of samples positive for the different viruses tested and denominator is the total number of samples tested.

associated with each of the samples (Table 2). Only $35.7 \%$ of the figs were positive for the Clostero-like virus, and of those, $80 \%$ were from a single location, the USDA National Clonal Germplasm Repository for figs at UC Davis. The luteovirus associated RNA-like virus was present in $34.6 \%$ of the tested samples, and the Umbravirus-like virus was detected in only $25 \%$ of samples (Table 2). However, the EMARAV-like virus was detected in $96 \%$ of the 184 samples tested.

Because all of the samples we collected and analyzed above showed symptoms of FM (essentially all figs grown outdoors in California show FM), this suggested to us that of all the viruses identified here, the EMARAV-like virus was the more likely candidate as causal agent of FM. Therefore, we initiated attempts to obtain virusfree fig seedlings so we could use them in transmission studies to attempt to confirm the causal agent of FM. We grew fig seedlings in a growth chamber and tested them by RT-PCR for the above virus sequences. None of the virus sequences identified by us were found in the fig seedlings. To test if EMARAV-like virus was transmissible and associated with FM characteristic symptoms, we next performed grafting experiments. We used budwood from fig trees that were previously ascertained by RT-PCR to have only the EMARAV-like virus (of the viruses we could detect). This budwood was then grafted onto the asymptomatic, virus-free seedlings. After 2 months, the resulting plants showed typical FM symptoms and were positive by RTPCR for the EMARAV-like virus. Thus, we did transmit the EMARAV-like virus by graft inoculation, and recipient plants showed FM. Taken together, these data show a consistent association of the EMARAV-like virus with FM.

\section{DISCUSSION}

Our work shows that fig trees can harbor a number of different viruses of different taxa. This study also shows the value of sequence/phylogenetic-based approaches to study and determine the etiology of difficult diseases, particularly those of perennial plants. Woody plants often contain polyphenolic compounds which offer technical difficulties for conventional virion extraction and/or RNA purification analyses. The extraction of dsRNA from affected tissues and further using dsRNAs to construct a cDNA library offers a way to identify even low titer RNA viruses. This approach has been successfully demonstrated by a recent dsRNA-based cDNA sequencing study of citrus trees affected with citrus sudden death (CSD) disease in Brazil (20). In that study, they prepared cDNA libraries to purified dsRNAs, and 109 , or $0.18 \%$, of their sequencing reads were to very low abundant virus sequences. Of these, only two sequences were for a putative member of the $T y$ - 
moviridae. RT-PCR analysis on 773 CSDaffected and healthy trees showed a $99.7 \%$ correlation for this new virus, which they called Citrus sudden death-associated virus (CSDaV), with trees showing CSD (20). CSDaV is a proposed member of the genus Marafivirus, but it is interesting and important to note that during their sequencing analyses for CSD, viruses of several other taxa also were identified. Only through careful and thorough survey analyses were they able to identify CSDaV as a likely candidate for causality.

The fact that fig trees can be associated with so many viruses is not surprising. Figs are propagated vegetatively by cuttings from parent trees; therefore systemic pathogens such as viruses, phytoplasmas, and even nonpathogenic microorganisms will be passed to new cuttings. Furthermore, current fig propagation does not utilize procedures to eliminate pathogens from the propagation materials. This is in part due to a lack of available virus detection tools that could ensure that only virusfree materials were used for propagation. We demonstrate the availability of tools for detecting a number of different figinfecting viruses. These tools can be of practical importance to fig propagators and to the agencies that would certify virusfree propagating materials.

It is also interesting and important to note the identification of Umbravirus-like and luteovirus-associated RNA-like sequences in many fig trees. Umbraviruses are helper-dependent upon members of the Luteoviridae (generally of the genus Polerovirus) for their aphid transmissibility $(10,29)$. Some umbraviruses are associated with important diseases such as carrot motley dwarf and groundnut rosette $(15,29)$. We don't yet know if the figassociated umbravirus is associated with any disease in figs, but we now have the tools to determine if this may be the case. The translated nucleotide sequence that showed high identity to a region of the RdRp of luteovirus-associated RNA is intriguing since only three such RNAs have been described previously. These are the Beet western yellows virus ST9associated RNA, Tobacco bushy top disease-associated RNA, and the Carrot red leaf virus-associated RNA $(10,23)$. These coat-dependent RNA replicons $(23,32)$ are only $\sim 2.8 \mathrm{~kb}$, encode for their own RdRp, and can have significant effects on infections with the helper Polerovirus $(4,23)$. The fact that we found umbravirus-like and luteovirus-associated RNA-like sequences from some of the fig trees analyzed here suggests that there may be a Luteovirus (Polerovirus?) also in some figs, and its association with the above virus agents could be interesting.

Although most of our sequences were to closteroviruses, the results from our survey clearly showed that the closterovirus identified by us is not associated with all the
FM-affected fig trees. Our survey results indicate that the fig-infecting closterovirus-like virus was present in almost $80 \%$ of the FM-affected trees from the USDA Fig germplasm collection but not in the majority of fig samples collected from other locations. Recent studies by Elbeaino et al. $(8,9)$ also identified closteroviruses in the figs, and they have named them FLMaV (Fig leaf mottle associated virus) 1 and 2. They found FLMaV-1 to be associated with 28 out of 37 symptomatic trees, but they also showed that it was present in 9 out of 20 asymptomatic trees. FLMaV-2 was found to be associated with 4 out of 57 symptomatic fig tree samples. These results support our conclusions that the closterovirus identified by us is not the causal agent of FM.

Ninety-six percent of the surveyed fig trees tested by us were positive for the EMARAV-like virus. This consistent association is certainly suggestive, but not proof for causality. Our RNA-based approaches and even our grafting experiments cannot completely rule out the possibility that another as yet unidentified virus may also be present but so far not identified in FM-affected figs. However, based on our data and previous work by others, we suggest the name Fig mosaic associated virus (FMaV) for the virus we described here.

Our efforts show a very high level of constant association of FMaV with FM, step 1 of Koch's postulates. Furthermore, previous ultrastructural studies showing DMPs and transmission using the fig eriophyid mite Aceria ficus $(13,24)$ suggest that the causal agent of FM is similar, or possibly related to, viruses that cause some diseases with similar properties including the High Plains disease of corn and wheat, rose rosette, wheat spot mosaic, Sterility mosaic disease of pigeon pea, and yellow ring spot of redbud $(16,18)$. Eriophyid mites are known to be the vectors of all the viruses associated with these diseases, and ultrastructural studies show presence of DMPs (16) in plants affected by these diseases. Only limited sequence information is available so far for two of these viruses, but the putative nucleocapsid protein for Maize red stripe virus (MRStV), which is associated with High Plains disease of corn and wheat (28), shows limited sequence similarity with the EMARAV putative nucleocapsid protein and also to FMaV.

Finally, analysis of our data and that for related viruses suggests that $\mathrm{FMaV}$ is most likely a negative-sense ssRNA plant virus and has multiple genomic RNA segments. The two FMaV sequences reported here show significant homology with corresponding sequences to two of the genomic RNAs of EMARAV. These are EMARAV genomic RNAs 2 and 3, encoding the EMARAV glycoprotein and nucleocapsid proteins, respectively (21). The predicted genome organization for EMARAV is that it is composed of four negative-sense ssRNA segments. The EMARAV genomic segments 2 and 3 are 2,335 and 1,560 nucleotides, respectively, similar to the estimates of $\sim 2.1$ and $\sim 1.8 \mathrm{~kb}$, respectively (Fig. 4), obtained by us for FMaV via northern hybridization analysis. EMARAV is the only four-component negative-sense RNA virus so far for which complete genome sequence information is available, but recent analyses for MRStV also suggest that four negative-sense ssRNAs might constitute the genome (28). These viruses, which share ultrastructural cytopathological properties, transmission by eriophyid mites (although the vector of EMARAV is not known), and sequence similarities, likely represent a newly recognized taxon of plant viruses.

\section{ACKNOWLEDGMENTS}

This research was supported in part by grants from the California Fig Advisory Board, the U.S. Department of Agriculture, The UC Davis Conservation of genetic resources program, and the University of California. Jeewan Jyot is grateful to the Ogawa Endowment Committee for partially supporting this research. The authors would like to acknowledge Mallikarjuna Aradhya and Ed Stover for helpful suggestions and providing access to USDA, National Clonal Germplasm Repository, University of California, Davis to collect samples and for providing the fig seedlings, and to Louise Ferguson for her help, enthusiasm, and encouragement. The authors thank Vicente Medina for his excellent pictures of symptomatic fig trees.

\section{LITERATURE CITED}

1. Anh, K. K., Kim, K. S., Gergerich, R. C., Jensen, S. G., and Anderson, E. J. 1996. Comparative ultrastructure of double membranebound particles and inclusions associated with eriophyid mite-borne plant diseases of unknown etiology: A potentially new group of plant viruses. J. Submicrosc. Cytol. Pathol. 28:345-355.

2. Blodgett, E. C., and Gomec, B. 1967. Fig Mosaic. Plant Dis. Rep. 46:693.

3. Bradfute, O. E., Whitmoyer, R. E., and Nault, L. R. 1970. Ultrastructure of plant leaf tissue infected by a mite-borne virus-like pathogens. Proc. Electron Microsc. Soc. Am. 28:178-179.

4. Chin, L. S., Foster J. L., and Falk, B. W. 1993. The Beet Western Yellows Virus St9-associated RNA shares structural and nucleotide-sequence homology with Carmo-Like Viruses. Virology 192:473-482.

5. Condit, I. J., and Horne, W. T. 1933. A mosaic of fig in California. Phytopathology 23:887-896.

6. Dodds, J. A., Morris, T. J., and Jordan, R. L. 1984. Plant viral double-stranded RNA. Annu. Rev. Phytopathol. 22:169-188.

7. Dolja, V. V., Kreuze, J. F., and Valkonen, J. P. 2006. Comparative and functional genomics of closteroviruses. Virus Res. 117:38-51.

8. Elbeaino, T., Digiaro, M., De Stradis, A., and Martelli, G. P. 2006. Partial characterization of a Closterovirus associated with a chlorotic mottling of fig. J. Plant Pathol. 88:187-192.

9. Elbeaino, T., Digiaro, M., De Stradis, A., and Martelli, G. P. 2007. Identification of a second member of the family Closteroviridae in mosaic diseased figs. J. Plant Pathol. 89:119-124.

10. Falk, B. W., Tian, T., and Yeh, H.-H. 1999. Luteovirus-associated viruses and sub-viral RNAs. Curr. Top. Microbiol. Immunol. 239:159-175.

11. Fauquet, C. M., Mayo, M. A., Maniloff, J., Desselberger, U., and Ball, L. A. 2005. Virus 
Taxonomy: Eighth Report of the International Committee on Taxonomy of Viruses. Academic Press, New York.

12. Ferguson, L., Michailides, T., and Shore, H. 1990. The California Fig Industry. Hortic. Rev. 11:409-490.

13. Flock, R. A., and Wallace, J. M. 1955. Transmission of Fig Mosaic by the eriophyid mite Aceria ficus. Phytopathology 45:52-54.

14. Germplasm Resources Information Network. U.S. Dep. Agric. Agric. Res. Serv. Online: http://www.ars-grin.gov/npgs/cgc_reports/woo dy2006/ncgrdavis2006.html.

15. Gibbs, M. J., Ziegler, A., Robinson, D. J., Waterhouse, P. M., and Cooper, J. I. 1996. Carrot mottle mimic virus (CMoMV): A second umbravirus associated with Carrot motley dwarf disease recognized by nucleic acid hybridization. Molecular Plant Pathol. online. http://www.bspp.org.uk/mppol/1996/1111gibbs/ index.htm.

16. Kim, K. S., Ahn, K. K., Gergerich, R. S., and Kim, S. B. 2001. Possible etiology of eriophyid mite-borne pathogens associated with double membrane bound particles. Pages 2950 in: Virus-Insect-Plant Interactions. K. F. Harris, O. P. Smith, and J. E. Duffus, eds. Academic Press, New York.

17. Kislev, M. E., Hartmann, A., and Bar-Yosef, O. 2006. Early domesticated fig in the Jordan Valley. Science 132:1372-1374.

18. Kumar, P. L., Duncan, G. H., Roberts, I. M., Jones, A. T., and Reddy, D. V. R. 2002. Cytopathology of Pigeon pea sterility mosaic virus in pigeon pea and Nicotiana benthemiana: Similarities with those of eriophyid mite borne agents of undefined etiology. Ann. Appl. Biol. 140:87-96.

19. Kumar, P. L., Jones, A. T., and Reddy, D. V. R.
2003. A novel mite-transmitted virus with a divided RNA genome closely associated with pigeon pea sterility mosaic disease. Phytopathology 93:71-81.

20. Maccheroni, W., Alegria, M. C., Greggio, C. C., Piazza, J. P., Kamla, R. F., Zacharias Paula, R. A., Bar-Joseph, M., Kitajima, E. W., Assumpca, L. C., Camarotte, G., Cardozo, J., Casagrande, E. C., Ferrari, F., Franco, S. F., Giachetto, P. F., Girasol, A., Jordao, H., Silva, V. H. A., Souza, L. C. A., Aguilar vildoso, C. I., Zanca, A. S., Arruda, P., Kitajima, J. P., Reinach, F. C., Ferro, J. A., and deSilva, A. C. R. 2005. Identification and genomic characterization of a new virus (Tymoviridae family) associated with citrus sudden death disease. J. Virol. 79:3028-3037.

21. Mielke, N., and Muehlbach, H. P. 2007. A novel, multipartite, negative-strand RNA virus is associated with the Ringspot disease of European mountain ash (Sorbus aucuparia L.) J. Gen. Virol. 88:1337-1346

22. Osman, F., Leutenegger, C., Golino, D., and Rowhani, A. 2007. Real-time RT-PCR (TaqMan (R)) assays for the detection of Grapevine Leafroll associated viruses 1-5 and 9. J. Virol. Methods 141:22-29.

23. Passmore, B. K., Sanger, M., Chin, L. S., Falk, B. W., and Bruening, G. 1993. Beet Western Yellows Virus-Associated RNA - an independently replicating RNA that stimulates virus accumulation. PNAS 90:10168-10172.

24. Proeseler, G. 1969. Transmission of the fig mosaic virus by the eriophyid mite Aceria ficus Cotte. Zentralbl. Bakteriol. Parasitenkd. Infektionskr. Hyg. 123(3):288-292.

25. Salem, N., Golino, D. A., Falk, B. W., and Rowhani, A. 2008. Identification and partial characterization of a new luteovirus associated with rose spring dwarf disease. Plant Dis. 92:508-512

26. Salem, N., Miller, W. A., Rowhani, A., Golino, D. A., Moyne, A. L., and Falk, B. W. 2008. Rose spring dwarf-associated virus has RNA structural and gene-expression features like those of Barley yellow dwarf virus. Virology 375:354-360.

27. Sambrook, J., and Russell, D. 2001. Molecular Cloning: A Laboratory Manual. 3rd ed. Cold Spring Harbor Laboratory, Cold Spring Harbor, New York.

28. Skare, J. M., Wikkamp, I., Denham, I., Rezende, J. A. M., Kitajima, E. W., Park, J. W. Desvoyes, B., Rush, C. M., Michels, G., Scholthof, K. C., and Scholthof, H. B. 2006. A new eriophyid mite-borne membraneenveloped virus-like complex isolated from plants. Virology 347:343-353.

29. Taliansky, M. E., and Robinson, D. J. 2003. Molecular biology of umbraviruses: Phantom warriors. J. Gen. Virol. 84:1951-1960.

30. Taliansky, M. E., Robinson, D. J., Waterhouse, P. M., Murant, A. F., de Zoeten, G. A., and Gibbs, M. J. 2005. Genus Umbravirus. Pages 901-906 in: Virus Taxonomy, Eighth Report of the International Committee on Taxonomy of Viruses. C. M. Fauquet, M. A. Mayo, J. Maniloff, U. Desselberger, and L. A. Ball, eds. Elsevier, Academic Press, San Diego.

31. Valverde, R. A., Nameth, S. T., and Jordan, R. L. 1990. Analysis of double-stranded RNA for plant virus diagnosis. Plant Dis. 74:255-258.

32. Watson, M. T., Tian, T., Estabrook, E., and Falk, B. W. 1998. A small RNA resembling the beet western yellows luteovirus ST9associated RNA is a component of the California carrot motley dwarf complex. Phytopathology $88: 164-170$. 